\title{
Infection and Colonization of Turf-Type Bermudagrass by Ophiosphaerella herpotricha Expressing Green or Red Fluorescent Proteins
}

\author{
Oliver C. Caasi, Nathan R. Walker, Stephen M. Marek, James N. Enis, and Thomas K. Mitchell
}

First, second, third, and fourth authors: Department of Entomology and Plant Pathology, Oklahoma State University, Stillwater 74078; and fifth author: Department of Plant Pathology, The Ohio State University, Columbus 43210.

Accepted for publication 23 December 2009.

\section{ABSTRACT}

Caasi, O. C., Walker, N. R., Marek, S. M., Enis, J. N., and Mitchell, T. K. 2010. Infection and colonization of turf-type bermudagrass by Ophiosphaerella herpotricha expressing green or red fluorescent proteins. Phytopathology 100:415-423.

Spring dead spot, caused by Ophiosphaerella herpotricha, is the most important disease of turf-type bermudagrass (Cynodon spp.) in the transition zone of the United States. Despite the importance of the disease, only limited information is available about the host-pathogen interaction at the cellular level. To evaluate the host plant interaction, an isolate of $O$. herpotricha expressing green fluorescent proteins (GFP) or red fluorescent proteins (tdTomato) was used to study the infection and colonization of roots and stolons of several bermudagrass cultivars. Roots of cultivars Tifway 419 and Midlawn were colonized similarly, resulting in extensive root necrosis, whereas an accession of Cynodon transvaalensis was less necrotic. The stele of $C$. transvaalensis roots was colonized but not those of Tifway 419 and Midlawn. For intact stolons, colonization was limited to the epidermis and defined macroscopic necrotic lesions were observed on Tifway 419 and Midlawn while $C$. transvaalensis stolon tissues remained mostly nonnecrotic. Internal colonization of stolons occurred when hyphae grew into wounds, resulting in necrosis in Tifway 419 and Midlawn, but not in C. transvaalensis. These studies suggest that the interaction of $O$. herpotricha with bermudagrass varies across host genotypes and the host tissues infected. The limited necrosis in $C$. transvaalensis tissues, though colonized, suggests an inherent tolerance to $O$. herpotricha.
Spring dead spot (SDS), caused by Ophiosphaerella herpotricha (Fr.) Walker; O. korrae (J. Walker and A.M. Smith) R.A. Shoemaker and C.E. Babcock, and O. narmari (J. Walker and A.M. Smith) Wetzel, Hubert, and Tisserat $(8,24,25,28,34)$, is the most damaging disease of turf-type bermudagrass species (Cynodon dactylon (L.) Pers.) and hybrid cultivars (Cynodon dactylon $\times$ C. transvaalensis Burtt-Davy) in regions of North America and Australia where grass undergoes dormancy during the winter (14, 24,26,27). Bermudagrasses are widely used for home and institutional lawns, athletic fields, parks, and golf courses and are often damaged by SDS. The disease is most severe where the stand is 3 years old or older, the turf maintenance and management is intensive, and normal cold-temperature-induced dormancy is delayed $(14,16,24)$. Disease symptoms appear as healthy plants break dormancy in the spring and initiate tillering and rhizome/ stolon growth. The resulting dead patches are typically circular and vary in size from $5 \mathrm{~cm}$ to $<1 \mathrm{~m}$ in diameter. The patches are perennial and can increase in size each succeeding year $(14,24)$. Reestablishment of bermudagrass into the patch occurs from the adjacent surviving plants in or around the affected area and can require months (29).

$O$. herpotricha is considered the primary causal agent of SDS in the midwestern region of North America $(24,35)$. The biology and ecology of the fungus is not well understood even though the disease was first described more than 50 years ago $(7,8,28)$. Temperature has been identified as an important factor influencing disease establishment; however, little is known about how this or other factors affect the interaction of the host and fungus at the

Corresponding author: N. R. Walker: E-mail address: nathan.walker@ okstate.edu

doi:10.1094/PHYTO-100-5-0415

(C) 2010 The American Phytopathological Society cellular level $(2,28,33)$. Studies on the infection and colonization of bermudagrass roots, crowns, stolons, and rhizomes by $O$. herpotricha are difficult given that these events generally occur in the soil and are not easily observed. All Ophiosphaerella species that cause SDS are ecologically classified as ectotrophic rootinfecting fungi. Ophiosphaerella spp. grow as dark brown, septate hyphae outside of bermudagrass roots and stolons, and produce finer hyphae which penetrate and infect the host tissues, a growth habit that has been likened to that of the oat take-all patch pathogen Gaeumannomyces graminis var. avenae (24). However, while $G$. graminis var. avenae forms simple hyphopodia or mycelial mats, $O$. herpotricha forms fine hyphae that fuse into large, dark, oblong infection mats, 60 to $400 \mu \mathrm{m}$ in diameter (24).

Previous cytological studies of a SDS fungus, $O$. korrae (previously Leptosphaeria korrae), reported the formation of sclerotia on infected roots and stolons surfaces and within the cortexes of infected roots (8). Hyphae of $O$. korrae corresponded with a brown occluding substance occurring within the xylem vessels of the roots. Infection of the stele was observed, although reported to be rare, and occurred later in disease development. Small brown flecks that turn into black or brown dry rot or necrotic tissues were observed on culm bases, rhizomes, stolons and roots. Additionally, Crahay et al. (7) described black, flask-shaped pseudothecia with thick necks on inoculated roots, but did not observe sclerotia or sclerotia-like bodies.

Utilization of fluorescent protein expression in transformed fungi has greatly aided the study and understanding of plant disease by allowing the direct visualization of host plant infection in situ $(11,13,22)$. Green fluorescent protein (GFP) is the reporter most frequently used to observe plant pathogens including bacteria, viruses, and fungi $(10,15,30,31)$. In fungi, in particular, GFP has facilitated cytological investigations into development, pathogenicity, and disease progression. GFP expression in the 
maize foliar pathogens, Cochliobolus heterostrophus and Colletotrichum graminicola, has been used to study cellular hostpathogen interactions and morphogenesis $(15,31)$. Root-pathogen interactions, such as Magnaporthe grisea with rice and Fusarium oxysporum with tomato, have been studied using GFP, which enabled the identification of previously unrecognized infection sites $(11,22)$. The interactions of avirulent fungal species or strains with nonhosts have likewise been studied using GFPexpressing transformants, revealing the many steps of the infection cycle at which disease is stopped (31) or fungal growth proceeds asymptomatically (3). The application of fluorescent protein reporter genes to the SDS pathosystem may greatly further our understanding of this disease. The objective of this research was to describe bermudagrass tissue penetration and colonization by isolates of the SDS pathogen, O. herpotricha, transformed to express GFP or red (tdTomato) fluorescent proteins (22), respectively.

\section{MATERIALS AND METHODS}

Bacterial cultures and plasmids. All strains of Escherichia coli were maintained on Luria-Bertani (21) and all strains of Agrobacterium tumefaciens AGL1 were maintained on Agrobacterium minimal medium (AMM) (9) supplemented with carbenicillin at $50 \mu \mathrm{g} \mathrm{ml}{ }^{-1}$. For culture of bacterial strains carrying plasmids, media were supplemented with kanamycin at $50 \mu \mathrm{g}$ $\mathrm{ml}^{-1}$ for plasmid maintenance. The binary plasmid pOHT-sGFP was constructed using the pCAMBIA1300 (CAMBIA, Canberra, $\mathrm{AU})$ as the backbone vector. The CaMV35S promoter and $h p h$ gene were removed using the $\mathrm{XhoI}$ and $B s t \mathrm{XI}$ restriction sites and replaced with the OHT fungal hygromycin resistance cassette (Aspergillus nidulans olic promoter, $h p h$, and the region reported to be Botrytis cinerea tubA terminator) amplified from the plasmid pLOB1 (20) (gift from J. van Kan, Wageningen University) using the primers 5'-CCGGCCATCATGTTGGCTGCAGCTGT GGAGCCGCAT-3' and 5'-CGCGCTCGAGAAGCTTGATATCT GTTAGTA-3' (engineered BstXI and XhoI sites underlined, respectively), digested with BstXI and $\mathrm{XhoI}$ and ligated into the recipient sites of pCAMBIA1300, generating pOHT. The sGFP cassette (Pyrenophora tritici-repentis ToxA promoter, sgfp, A. tumefaciens nos terminator) was amplified from pCT74 (13) (gift from L. Ciuffetti, Oregon State University) using the primers $5^{\prime}$ GCGCGAGCTCTATCGATTGGAATGCATGGGAGG-3' (SacI site underlined) and T7 5'-TAATACGACTCACTATAGGG-3'. The amplified sGFP product and pOHT were digested with SacI and $X b a \mathrm{I}$, purified, and ligated to generate pOHT-sGFP. The plasmid pBHt2-tdTom was constructed by cloning a commercially synthesized ToxA promoter, tdTomato, nos terminator cassette (Codon Devices, Inc., Cambridge, MA; tdTomato sequence from Shaner et al. [23]) into the EcoRI site of pBHt2 (18) (gift from S. Kang, Pennsylvania State University).

Fungal cultures and transformation. $O$. herpotricha does not sporulate in culture or produce protoplasts when treated with commercially available cell wall degrading enzymes. As such, an A. tumefaciens-mediated transformation (ATMT) protocol was developed using fragmented mycelia to generate stable transformed lines expressing green (sGFP) and red (tdTom) fluorescing proteins. An isolate of $O$. herpotricha strain KS188 (originally isolated from bermudagrass with SDS in Afton, OK) was maintained on potato dextrose agar (PDA; EMD Chemicals, Gibbstown, NJ) and incubated at $25^{\circ} \mathrm{C}$. The ATMT method was used to transform $O$. herpotricha hyphae (17), based on a modified ATMT procedure of Mullins et al. (18). Briefly, to generate hyphal fragment suspensions used for ATMT, a $0.5 \mathrm{~mm}$ agar plug was excised from the colony margin of a 5-day-old PDA culture of $O$. herpotricha and placed with $1 \mathrm{ml}$ of sterile water and two $3 \mathrm{~mm}$ glass beads in a 2-ml screw cap tube and homogenized at $5,000 \mathrm{rpm}$ for $30 \mathrm{~s}$ using a bead-beater (BioSpec Products, Bartlesville, OK).
Virulence was induced in 2-day-old AMM broth (supplemented with the appropriate antibiotics) cultures of $A$. tumefaciens AGL1 (no vector negative control) or A. tumefaciens AGL1 carrying either pOHT-sGFP or pBHt2-tdTom, by pelleting cells by centrifugation and resuspending in inducing minimal medium (IMM, supplemented with $200 \mu \mathrm{M}$ acetosyringone and appropriate antibiotics) (4) to an optical density at $600 \mathrm{~nm}\left(\mathrm{OD}_{600}\right)$ of 0.2 . IMM cultures were incubated overnight at $28^{\circ} \mathrm{C}$ with $250 \mathrm{rpm}$ shaking, pelleted by centrifugation, and again resuspended in appropriately supplemented IMM to an $\mathrm{OD}_{600}$ of 0.2 . These virulence-induced $A$. tumefaciens suspensions were each mixed with $O$. herpotricha hyphal fragment suspensions 1:1 (vol/vol), spread onto nitrocellulose membranes overlaid on appropriately supplemented IMM plates, and co-incubated for 48 to $72 \mathrm{~h}$ at $20^{\circ} \mathrm{C}$. After which, membranes were transferred, mycelium-side-down, onto yeast extract-peptone-sugar (YPS, $0.1 \%$ yeast extract, $0.1 \%$ peptone, $0.1 \%$ glucose, and $1.7 \%$ agar) basal medium plates containing hygromycin $\mathrm{B}$ at $50 \mu \mathrm{g} \mathrm{ml}^{-1}$, cefotaxime at $200 \mu \mathrm{g} \mathrm{ml}^{-1}$, and timentin at $100 \mu \mathrm{g} \mathrm{ml}^{-1}$ to select fungal transformants and kill A. tumefaciens. Selection plates were incubated at $20^{\circ} \mathrm{C}$ for 1 to 2 weeks before hygromycin-resistant colonies were transferred to YPS supplemented with hygromycin at $50 \mu \mathrm{g} \mathrm{ml}^{-1}$ (YPSH) and incubated at room temperature for 4 to 5 days. The hyphae of each transformant were evaluated for relative green or red fluorescence using a Nikon Eclipse E800 epifluorescent microscope (Nikon Instruments Inc., Melville, NY). The in vitro cultural appearance and growth rate of each transformant also were evaluated and those found comparable to the nontransformed parent strain of $O$. herpotricha selected. Selected transformants were purified by serially subculturing hyphal tips of each transformant on YPSH three times. Transgene stability was confirmed by serially subculturing each transformant on YPS three times and then back to YPSH. DNA was isolated from mycelia of wild-type and transformed $O$. herpotricha (5), and the presence of transgenes in each transformant confirmed using polymerase chain reaction (PCR) and primers hybridizing with $h p h$ (5'-GCCG ATGCAAAGTGCCGATAAACA-3') and either $s g f p$ (5'-AAGT CGTGCTGCTTCATGTG-3') or tdtomato (5'-AGCGCATGAA CTCTTTGATGACGG-3') of the T-DNA, respective of the binary vector used.

Bermudagrass cultivation and root inoculation. A modified soilless assay system developed by Walker et al. (32) was used in this study. Stolons of bermudagrass cultivars Tifway 419 and Midlawn and a $C$. transvaalensis accession were washed several times with reverse osmosis ( $\mathrm{RO})$ water and rinsed with sterile distilled water twice and cut into 2 to $5 \mathrm{~cm}$ segments, each containing at least one node. Stolon segments were transferred to sterile rockwool (Inside Sun Co., Indianapolis, IN) for rooting and watered with sterile RO water. After 3 to 5 days, stolons with roots were selected and transferred individually to sterile petri plates $(100 \times 15 \mathrm{~mm}$, VWR, Batavia, IL) lined with a double layer of wet white paper towel and placed on a microscope slide $(3 \times 1 \times 1 \mathrm{~mm}$, Fisher Scientific Inc., Pittsburgh, PA). The plates were saturated with sterile RO water. A single root from each stolon was inoculated with a mycelial agar plug (approximately $0.25 \mathrm{~mm}$ in diameter) from the colony margin of a 10- to14-dayold PDA plate of $O$. herpotricha wild type or transformants D5 (GFP) or B6 (tdTomato) placed near the root. One noninoculated plant for every five inoculated replicates was used as a control. Plates were sealed with parafilm and were incubated upright in a growth chamber (Conviron E7, Controlled Environments Ltd., Manitoba, Canada) at $17^{\circ} \mathrm{C}$ and $12 \mathrm{~h}$ light (400 micromoles $\left./ \mathrm{m}^{2} / \mathrm{s}\right)$. This study was repeated four times.

Root dip inoculation of bermudagrass for disease severity evaluation. Mycelia of $O$. herpotricha B6 expressing tdTomato (red) fluorescent protein were scraped from three PDA plates. Mycelia were transferred into $50 \mathrm{ml}$ of sterile water in a sterile blender (Waring Commercial, Torrington, CT) and homogenized, 
and the resulting suspension was transferred to a sterile beaker. Bermudagrass stolon segments with roots, grown as before, were washed with sterile RO water twice. Ten plants of each cultivar were tied together with sterile cotton string and washed once more with sterile RO water and then dipped in the mycelial fragment suspension for $2 \mathrm{~min}$. Bundles were untied and the inoculated plants were aligned side by side in a sterile double layer of wet paper towels. The wet paper towels were rolled, each inserted in a sterile 50-ml polypropylene centrifuge tube (Fisher Scientific, Pittsburgh, PA), and all plants were incubated in a growth chamber (Conviron E7) for 14 days at $17^{\circ} \mathrm{C}$ and $12 \mathrm{~h}$ light. This study was repeated once.

Inoculation of bermudagrass stolons. Plants were propagated as described previously and stolon internodes were inoculated directly with an agar plug (approximately $0.25 \mathrm{~mm}$ in diameter) from the colony margin of an actively growing PDA culture of $O$. herpotricha B6 expressing red (tdTomato) fluorescent protein. This study was repeated once. Additionally, stolons of root-dipinoculated plants were examined (described below).

Microscopy. Roots were repeatedly observed microscopically from 1 day postinoculation (DPI) to 14 DPI. Some roots were embedded in 3\% agarose (Promega Corp., Madison, WI) and hand-sectioned with a surgical blade (Bard-Parker, Becton Dickinson Acute Care, Franklin Lake, NJ). Stolons were observed at 3,14, and 28 DPI. In some cases, stolons from root-inoculated plants were observed 28 DPI. Some stolons were hand-sectioned identically as roots. Inoculated and noninoculated whole roots and stolons and transverse and longitudinal hand sections of each were mounted in water and observed with a Nikon Eclipse E800 microscope equipped with mercury-arc lamp and the following epifluorescence filter sets (and respective cellular fluorescence observed): UV-2E/C DAPI (autofluorescence and necrosis), Endow GFP HYQ long pass (GFP and autofluorescence), GFP-3035B (GFP only) and G-2E/C TRITC (red fluorescent protein and root autofluorescence). Digital images were captured using a monochrome QImaging Retiga 2000R charge-coupled device (CCD) camera (Quantitative Imaging Corp., Surrey, BC, Canada). Composites images of single-color, bandpass images (grayscale) were artificially colored and combined as layers using QCapture Pro version 5.1.1.14, the camera's image capture program. Macroscopic images of roots were captured using a Nikon SMZ-2T stereomicroscope (Nikon Inc., Tokyo, Japan) equipped with an Olympus DP71 digital camera (Olympus Imaging America Inc., Center Valley, PA).

Disease severity ratings. The necrotic responses of bermudagrass roots to $O$. herpotricha were assessed at 14 DPI. Macroscopic lesions were rated on a 0 to 5 scale as follows: $0=$ no root discoloration, 1 = yellow root discoloration without necrotic lesions, 2 = scattered, small light brown lesions $(<25 \%$ of root), $3=$ scattered dark brown lesions $(<25 \%$ of root $), 4=$ large contiguous dark brown to black lesions $(<50 \%$ of root $)$, and $5=$ dark brown to black necrosis of most of the root ( $>50 \%$ of root). Microscopic epidermal lesions also were observed and assessed epifluorescently with the E800 microscope at 100x magnification using the UV filter, with which necrotic host cells appeared black (fluorescence quenched) and healthy root cells fluoresced blue. A scale of 0 to 3 was used to assess the extent of necrosis as follows: $0=$ no symptoms, $1=$ less severe with only small necrotic lesions covering less than $25 \%$ of the root, $2=$ moderately severe with necrotic lesions covering less than $50 \%$ of the root, and $3=$ extremely severe with necrotic lesions covering more than $50 \%$ of the root.

Root colonization by $O$. herpotricha was assessed and related to necrosis by pseudocoloring and merging monochrome images captured with the UV (necrosis), GFP (O. herpotricha hyphae of GFP transformants), and TRITC (host cell autofluorescence and $O$. herpotricha hyphae of tdTomato transformants) filters. A scale of 0 to 3 was used as follows: $0=$ no hyphae observe on or in root, 1 = few ectotrophic hyphae on root, 2 = loosely interwoven ectotrophic hyphae and few hyphal aggregates covering less than $50 \%$ of the root surface, and $3=$ densely interwoven hyphae and numerous hyphal aggregates covering more than $50 \%$ of the root surface. Transverse sections of inoculated and noninoculated roots also were observed epifluorescently, as described previously.

Statistical analysis was conducted with SAS (version 9.2, SAS Institute, Cary, NC) using the GLIMMIX procedure to determine the significance of the main effects and interactions between studies. The log link function and Poisson distribution were utilized. Treatment differences were obtained using the LSMEANS statement in the GLIMMIX procedure to evaluate cultivar effects across experiments.

\section{RESULTS}

Transformation of $\boldsymbol{O}$. herpotricha. Following transformation, 23 hygromycin-resistant colonies were selected from primary hygromycin selection plates for each binary vector, pOHT-sGFP and pBHt2-tdTom. No hygromycin-resistant colonies were recovered from mycelial fragments co-incubated with virulenceinduced A. tumefaciens AGL1 lacking a binary vector. Six transformants with bright green fluorescence and 13 with bright red fluorescence were purified by serial transfer and shown to be stable in the absence of hygromycin selection. T-DNA integration in each line was confirmed by PCR. In vitro growth rates and colony morphology of each transformant appeared identical to the wild type, with the exception that the young mycelia of sGFPexpressing strains appeared slightly yellow and the young mycelia of tdTomato-expressing transformants appeared slightly pink in ambient lighting. Mycelia of all transformed and nontransformed isolates turned tan to brown after 7 days. Transformant D5, expressing GFP, and transformant B6, expressing tdTomato, were selected for all subsequent cytological investigations.

Root necrosis and colonization ratings of roots. Three bermudagrasses were used in this study, Midlawn, Tifway 419, and an accession of $C$. transvaalensis. The roots of each plant

TABLE 1. Root disease severity for three turf-type bermudagrasses infected by a tdTomato expressing isolate of Ophiosphaerella herpotricha 14 days after inoculation

\begin{tabular}{lccc}
\hline Cultivar/accession & $\begin{array}{c}\text { Macroscopic } \\
\text { epidermal } \\
\text { lesions }^{\mathrm{x}}\end{array}$ & $\begin{array}{c}\text { Microscopic } \\
\text { epidermal } \\
\text { lesions }^{\mathrm{y}}\end{array}$ & $\begin{array}{c}\text { Microscopic } \\
\text { epidermal } \\
\text { colonization }^{\mathrm{z}}\end{array}$ \\
\hline Tifway 419 & $3.65 \mathrm{a}$ & $2.55 \mathrm{a}$ & $2.95 \mathrm{a}$ \\
Midlawn & $2.90 \mathrm{~b}$ & $2.10 \mathrm{a}$ & $2.05 \mathrm{~b}$ \\
Cynodon transvaalensis & $1.40 \mathrm{c}$ & $1.40 \mathrm{~b}$ & $1.45 \mathrm{c}$ \\
\hline
\end{tabular}

${ }^{x}$ Roots were observed visually based on a scale of 0 to 5 as follows: $0=$ no root discoloration, 1 = yellow root discoloration without necrotic lesions, $2=$ scattered small light tan brown lesions ( $<25 \%$ of root), $3=$ root discoloration with scattered solid or limited dark lesions ( $<25 \%$ of root), $4=$ root discoloration with large dark solid lesions and very visible $(<50 \%$ of root), and $5=$ root discoloration with necrosis on almost entire root $(>50 \%$ of root). Means of 20 plants per cultivar. Means within the same column followed by the same letter are not significantly different by PROC GLIMMIX, LSMEANS ( $\alpha=0.05)$.

y Observed using an epifluorescence microscope at $\times 100$ with UV-2E/C DAPI (330 to $380 \mathrm{~nm}$ excitation) filter. Based on a scale of 0 to 3 as follows: $0=$ no symptoms, $1=$ less severe with only small necrotic lesions covering less than $25 \%$ of the root, $2=$ moderately severe with necrotic lesions covering less than $50 \%$ of the root, and $3=$ extremely severe with necrotic lesions covering more than $50 \%$ of the root.

${ }^{z}$ Observed using an epifluorescence microscope at $\times 100$ with GFP-3035B (457 to $487 \mathrm{~nm}$ excitation) filter for root autofluorescence and G-2E/C TRITC (528 to $553 \mathrm{~nm}$ excitation) filter for red fluorescence detection. Based on a scale of 0 to 3 as follows: $0=$ no infection or colonization, $1=$ colonization with few ectotrophic hyphae on root, 2 = less aggregated and loosely interwoven hyphae covering less than $50 \%$ of the root surface, and $3=$ densely interwoven and aggregated hyphae embracing more than $50 \%$ of the root surface. 


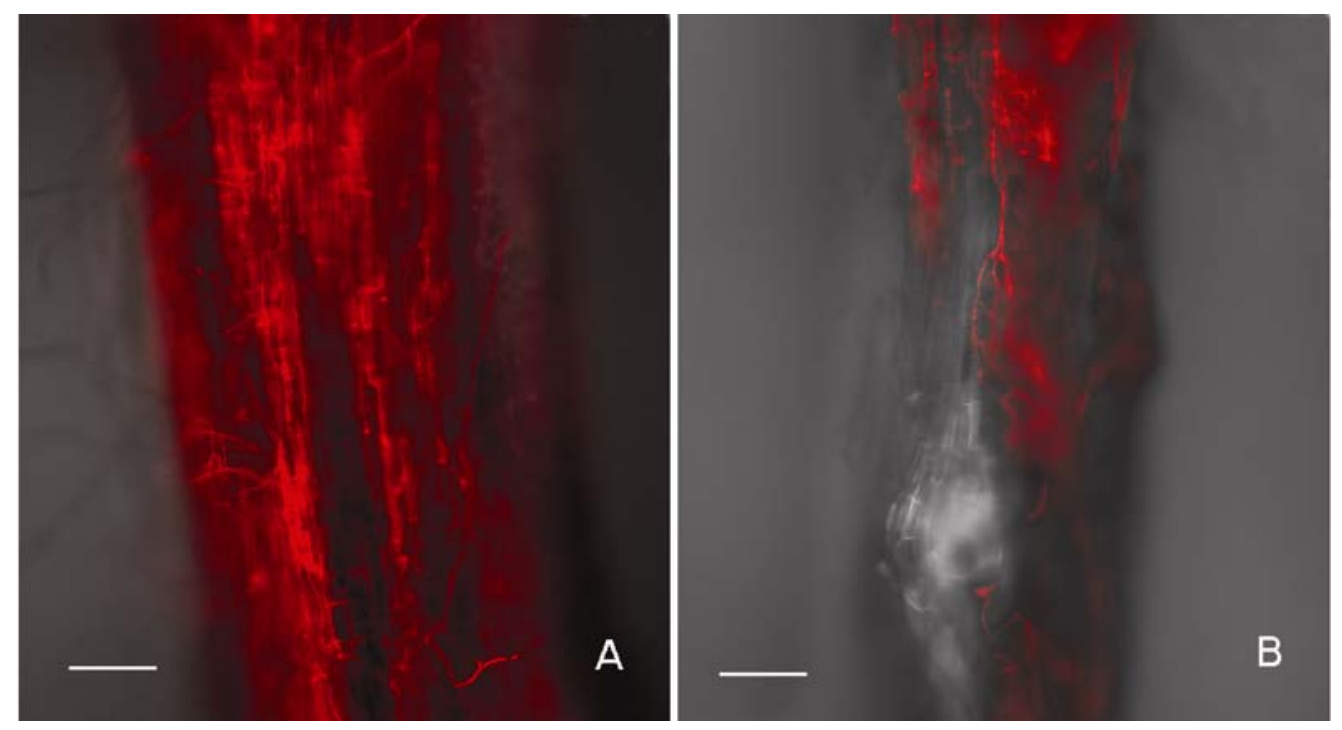

Fig. 1. Colonization of bermudagrass roots by an isolate of Ophiosphaerella herpotricha expressing tdTomato protein 14 days after roots were placed in a suspension containing mycelial fragments. A, Roots of cultivar Tifway 419 with extensive colonization. B, Roots of cultivar Midlawn with less colonization. Images were generated using filter sets UV-2E/C DAPI and G-2E/C TRITC. Bars represent $100 \mu \mathrm{m}$.
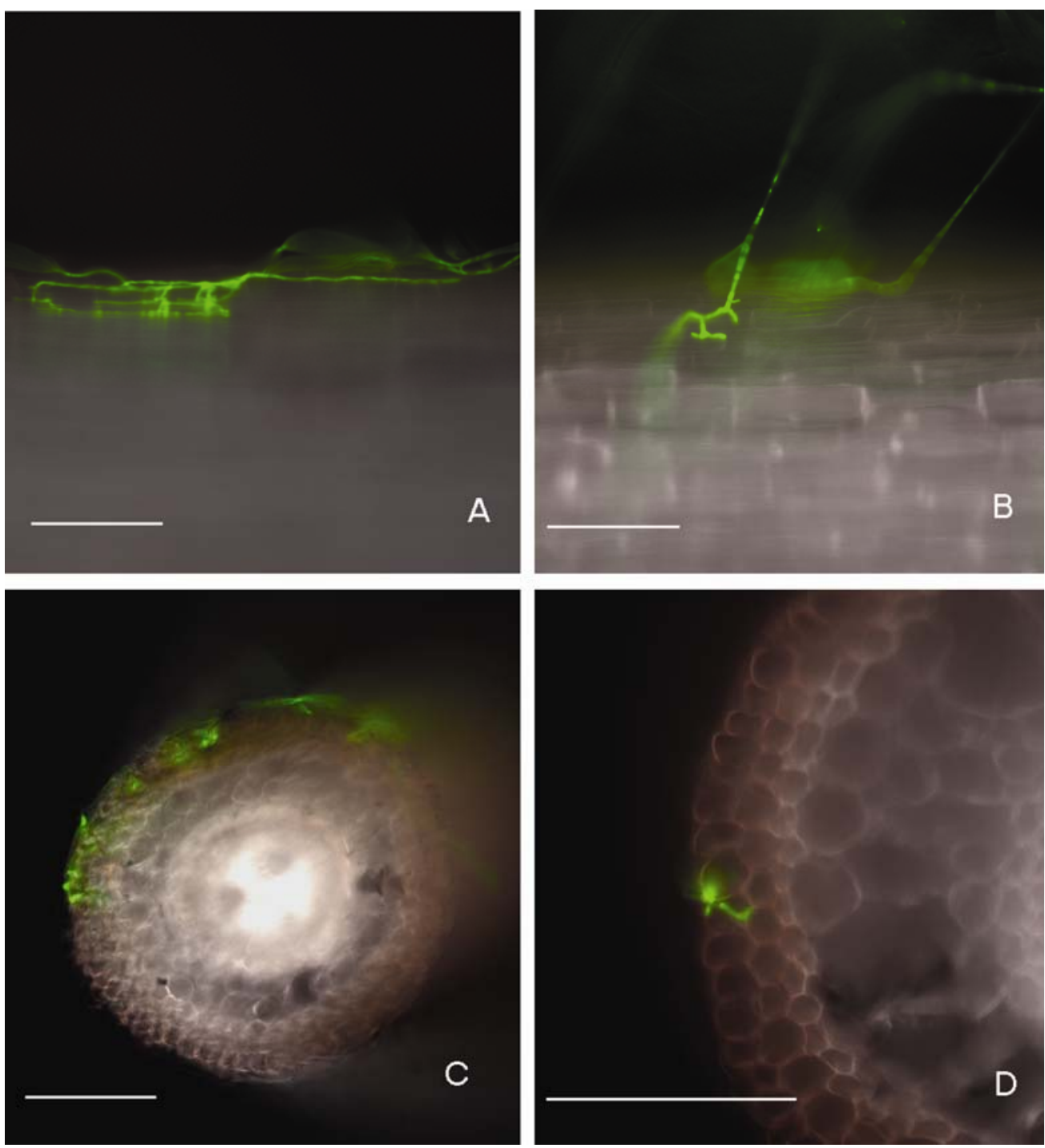

Fig. 2. Establishment of infection and colonization of bermudagrass roots by an isolate of Ophiosphaerella herpotricha expressing green fluorescent protein 2 days postinoculation. A, Initial direct penetration of roots of cultivar Tifway 419 and $\mathbf{B}$, a Cynodon transvaalensis accession. Transverse sections of roots indicating that hyphae have grown into root epidermis of Tifway 419, C, and a C. transvaalensis accession D. Bars represent $100 \mu \mathrm{m}$. 
displayed different disease reactions with regard to macroscopic and microscopic lesion development and root surface colonization at 14 DPI (Table 1). Tifway 419 had the highest macroscopic root epidermal lesions severity ratings among the three plants and $C$. transvaalensis had the lowest. While no differences were observed in microscopic root epidermal lesion ratings between Midlawn and Tifway 419, fewer microscopic lesions were observed on the roots of $C$. transvaalensis.

Fungal colonization ratings, based on the amount of red fluorescent hyphae observed at 14 DPI, varied as well. Tifway 419 roots were colonized to the highest level, while Midlawn roots were moderately colonized (Table 1; Fig. 1). C. transvaalensis had lowest level of root surface colonization. Overall, Tifway 419 had the highest levels of root necroses and fungal colonization, followed by Midlawn, and then C. transvaalensis.

Infection and colonization of roots. After inoculation, hyphae from the agar plug grew radially and did not orient specifically towards the roots for either cultivar or C. transvaalensis. When hyphae came into contact with the root surface, there was no specific attraction to root hairs, the hyphae either grew along the longitudinal axis, formed loosely interwoven networks of ectotrophic hyphae, penetrated the epidermis, or did both (Fig. 2A and B). Formation of hyphopodia was not observed prior to penetration and the fungus appeared to penetrate the epidermal cells directly (Fig. 2B). By 2 DPI, aggregates of hyphae were present in and around penetrated epidermal cells. On Tifway 419 roots at 2 DPI, the fungus began to colonize the root epidermis inter- cellularly and grew into the cortex (Fig. 2C). Over the next 2 days, the fungus ramified between cortical cells, some of which became necrotic. For $C$. transvaalensis roots at 2 DPI, growth into the outer cortex was also evident (Fig. 2D). Similar events were observed for Midlawn, with the infection restricted to the epidermal layer (not shown).

Colonization of roots was more rapid 4 DPI and hyphae were observed to spread ectotrophically on roots (Fig. 3A). At the initial point of infection, hyphae formed aggregates and epidermal necrosis was present (Fig. 3B). Colonization continued to progress for all cultivars but differences among the grasses became apparent. For Midlawn, macroscopic root lesions developed and grew larger between 5 and 8 DPI, with hyphae extending into the cortex. Notably, infected Midlawn cells adjacent to intercellular hyphae did not immediately appear necrotic. At 5 DPI, the cortical layer of $C$. transvaalensis near and around the vascular core was intensively colonized with tan to brown macroscopic lesions of root epidermal cells present by 8 DPI. Vascular infection of $C$. transvaalensis roots was observed at 8 DPI within the endodermis near the xylem-phloem bundle; however, the vascular region did not appear necrotic (Fig. 3C). Macroscopic root lesions were first observed on Tifway 419 and developed into larger lesions at 5 to 8 DPI with the occurrence of dark brown lesions 4 to $8 \mathrm{~mm}$ in length with mats of densely interwoven hyphae (Fig. 3D). Necrosis and colonization of Tifway 419 epidermal and cortical cells was extensive during this period and collapse of these tissues was evident.
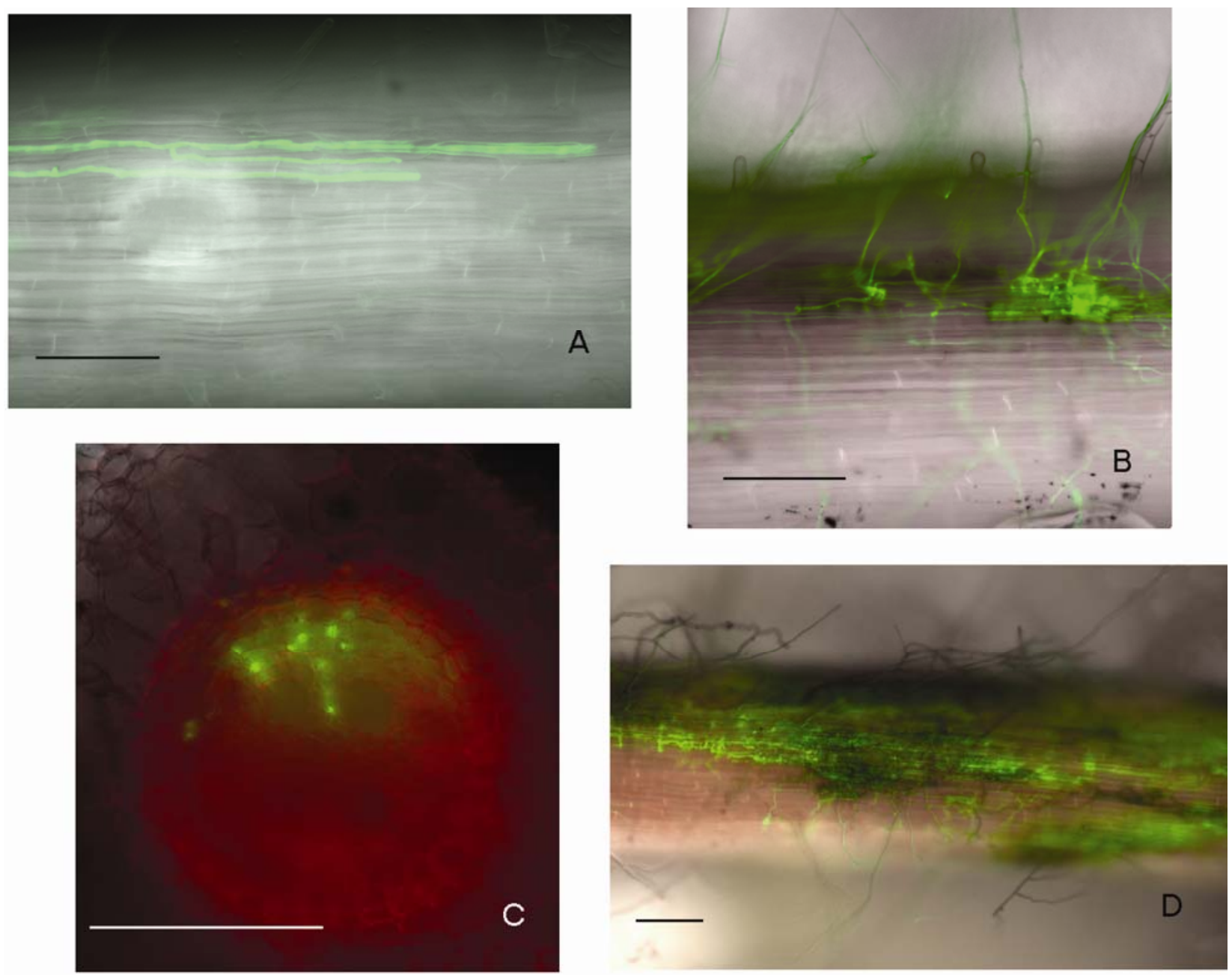

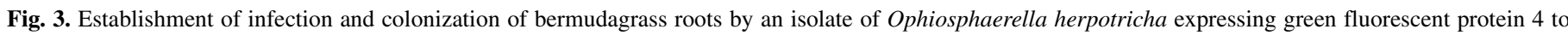

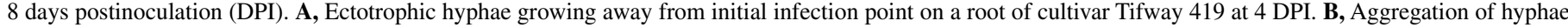

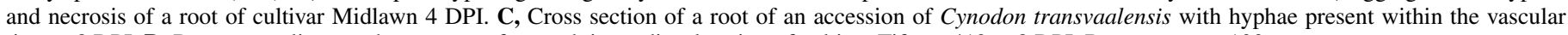
tissues 8 DPI. D, Dense mycelia growth on root surface and tissue discoloration of cultivar Tifway 419 at 8 DPI. Bars represent $100 \mu$ m. 
At 10 DPI, lesions along Midlawn roots were dark and cellular collapse was evident (Fig. 4A). Colonization of the inner cortical layer occurred but generally not until 10 DPI (not shown). A network of hyphae on $C$. transvaalensis roots was observed at 10 DPI; however, the hyphae were less aggregated than those observed on the other two cultivars (Fig. 4B). Even though epidermis, cortex, and the vascular stele of $C$. transvaalensis roots were extensively colonized, cell wall collapse was not observed. Extensive colonization and necrosis of epidermal and cortical cells and aggregations of hyphae inside epidermal cells of Tifway 419 roots were observed by 10 DPI (Fig. 4C).

By 14 DPI, the epidermis, cortex, and stele of $C$. transvaalensis was extensively colonized but with no evidence of necrosis (Fig. 5A). At 14 DPI, Tifway 419 roots were extensively colonized by O. herpotricha hyphae and displayed extensive cell necrosis (Fig.
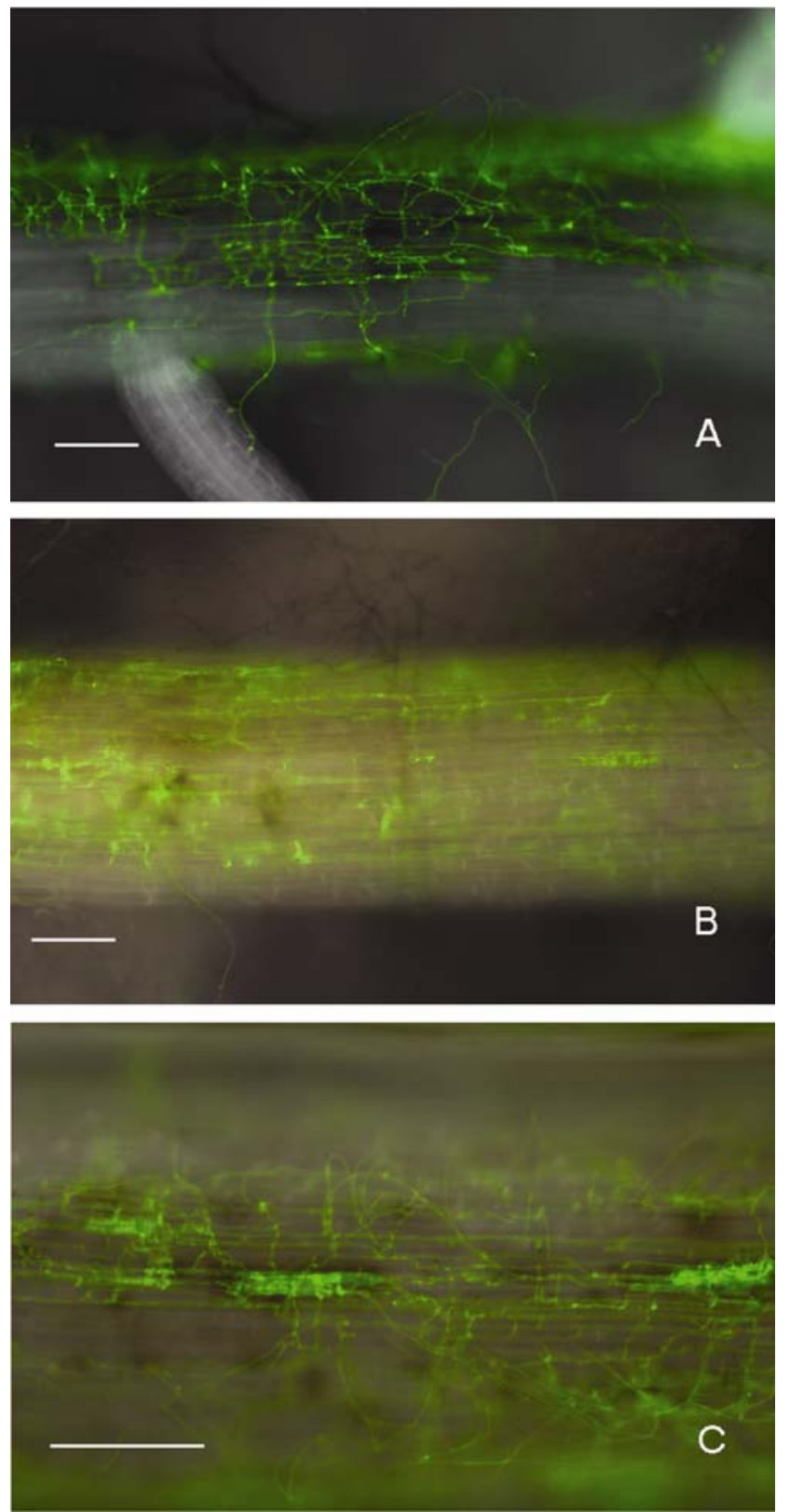

Fig. 4. Colonization of bermudagrass roots by an isolate of Ophiosphaerella herpotricha expressing green fluorescent protein 10 days postinoculation. A, Cultivar Midlawn root segment with extensive colonization and tissue necrosis. Image generated using filter sets UV-2E/C DAPI and GFP HYQ. B, A Cynodon transvaalensis accession root entirely colonized by hyphae but not exhibiting tissue necrosis. C, Cultivar Tifway 419 root segment with extensive colonization, hyphal aggregations, and tissue necrosis. Bars represent $100 \mu \mathrm{m}$.
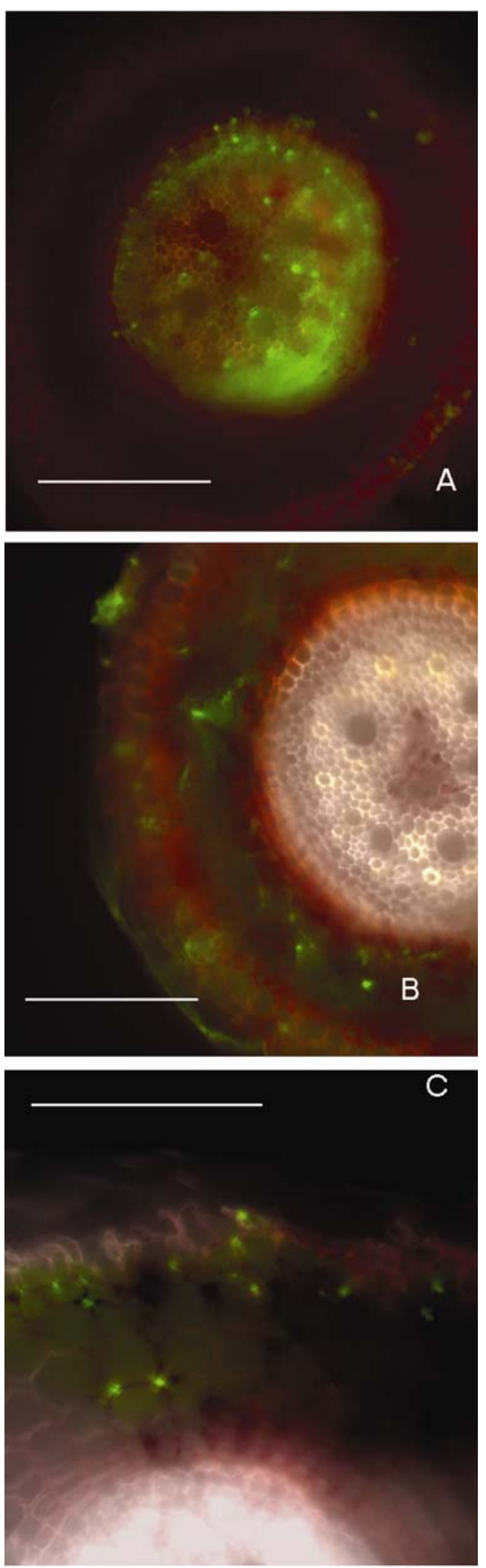

Fig. 5. Colonization of bermudagrass roots by an isolate of Ophiosphaerella herpotricha expressing green fluorescent protein 12 to 14 days postinoculation (DPI). A, Cross section of a root of accession Cynodon transvaalensis with extensive colonization within vascular tissues 14 DPI. B, Cross section of a root of cultivar Tifway 419 with hyphal colonization limited to epidermis and cortical tissues 14 DPI. C, Cross section of a root of cultivar Midlawn with hyphal colonization limited to epidermis and cortical tissues 12 DPI. Bars represent $100 \mu \mathrm{m}$. 
5B). Hyphal colonization of Tifway 419 roots was primarily intercellular in epidermal and cortical layers, with limited intracellular growth. The necrotic responses did not appear to limit either intra- or intercellular fungal growth. Ectotrophic hyphae on Tifway 419 roots were less aggregated at the point of emergence of secondary or lateral roots, however necrosis was present in these locations. Midlawn roots showed a similar but slower overall reaction to infection by $O$. herpotricha compared with Tifway 419. Similar to Tifway 419, the vascular region of Midlawn roots remained free of hyphal colonization (Fig. 5C).

Infection and colonization of stolons. The surfaces of stolons inoculated at the internode with tdTomato-expressing $O$. herpotricha B6 were colonized by ectotrophic hyphae at 3 DPI (Fig. 6A). Penetration of stolon epidermis was not observed in any transverse sections at 3 and 14 DPI (not shown). By 28 DPI, a network of hyphae, intermixed with hyphal aggregates, was attached to stolon surfaces of both cultivars and C. transvaalensis (Fig. 6B). In addition, hyphal mats (200 to $400 \mu \mathrm{m})$ were observed near the location of inoculation on the surfaces of Tifway 419 and Midlawn stolons, but were absent on C. transvaalensis stolons (Fig. 6C). Overall, stolon colonization and necrosis were slightly greater and faster on Tifway 419 stolons than on Midlawn stolons, with no other apparent differences observed between these two cultivars. At 28 DPI, more extensive colonization of stolon surfaces by ectotrophic hyphae, fewer hyphal aggregates, and less necrosis were observed on $C$. transvaalensis stolons than on Tifway 419 or Midlawn stolons (not shown).

The stolons of plants used for the root-dip colonization and necrosis studies were observed at 28 DPI, by which time hyphae had grown into stolon tissues. Longitudinal sections of these stolons revealed colonization that began at the cut end of stolon for all grasses. For Tifway 419 (Fig. 7A) and Midlawn (not shown) extensive colonization occurred in the hollow center of the stolons. Stolons of root-inoculated $C$. transvaalensis plants were extensively colonized, with numerous apparently intercellular hyphae in the outer and central tissues of the stolon. However, C. transvaalensis did not appear to possess a hollow stolon center (Fig. 7B).

\section{DISCUSSION}

The use of fluorescent protein expressing fungi to study hostpathogens interactions has been successfully used for many fungal pathosystems $(11,13,15,31)$. We generated transgenic isolates of $O$. herpotricha expressing two fluorescent proteins, GFP or tdTomato using ATMT of mycelial fragment. To our knowledge, this is the first report of a fungus transformed to express tdTomato. Based on initial evaluations, disease progression of transgenic isolates of $O$. herpotricha were indistinguishable from nontransgenic isolates. The observations of $O$. herpotricha infection and colonization of bermudagrass roots at the cellular level could not have been readily observed using traditional light microscopy without extensive and challenging histological procedures.

Previously, the infection and colonization of bermudagrass roots by $O$. herpotricha was characterized as being similar to that of the take-all patch fungus $G$. graminis var. avenae. It was suggested that Ophiosphaerella spp. form hyphopodia and infection cushions for penetration and colonization $(1,6,24)$. However, simple or lobed hyphopodia were not observed in this study. Instead, hyphae of $O$. herpotricha appeared to directly penetrate roots. Fusions of ectotrophic hyphae on root surfaces, which formed infection cushion-like aggregates, occurred only at later stages after penetration. After penetration through the epidermal layer, the cortex was colonized by most intercellular hyphae growing longitudinally along the root axis, as well as some hyphal branches growing transversely between host cells. Smiley et al. (24) described the accumulation of Ophiosphaerella ecto- trophic hyphae at the junctions between primary and secondary roots. While observed in this study, colonization at these junctions did not appear to be the primary points of penetration.

During the initial 2 days following inoculation, the interaction of $O$. herpotricha with roots of all three bermudagrasses did not differ. $O$. herpotricha hyphae did not selectively adhere to root hairs or lateral roots to initiate infection of Cynodon spp., unlike what was reported for Fusarium oxysporum infection of tomato roots (19). As colonization progressed on root surfaces, necrotic lesions developed and were more visible and larger in roots of cultivars Tifway 419 and Midlawn than in C. transvaalensis roots. In most cases, $C$. transvaalensis roots did not appear to respond with necrosis to the initial infections, though some yellow tissue discoloration developed much later (after 14 DPI). Using a semiquantitative rating scale based on the severity of root necrosis at $14 \mathrm{DPI}$, Tifway 419 and Midlawn were more susceptible than
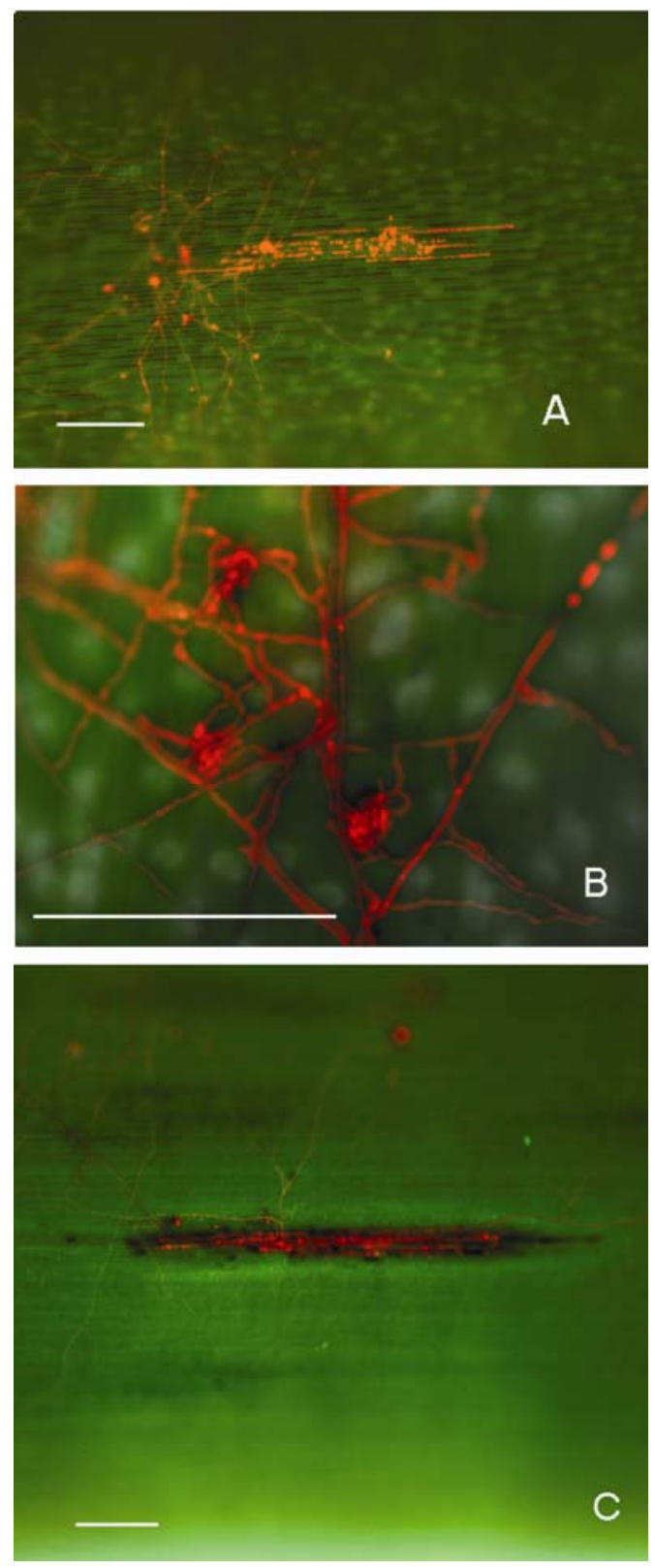

Fig. 6. Colonization of bermudagrass stolon by an isolate of Ophiosphaerella herpotricha expressing tdTomato fluorescent protein. A, Surface colonization of stolon of cultivar Tifway 419 at 3 days postinoculation (DPI). B, Hyphal aggregations on the stolon surface of Tifway 419. C, Hyphal colonization and necrosis on the stolon surface of cultivar Midlawn at 28 DPI. Bars represent $100 \mu \mathrm{m}$. 

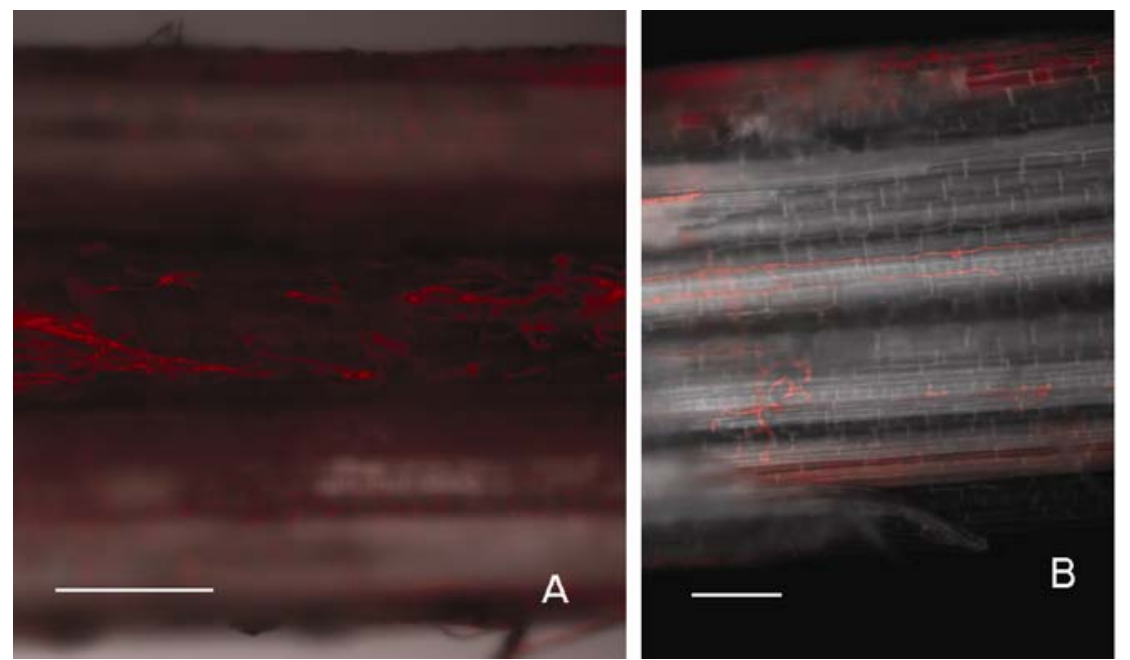

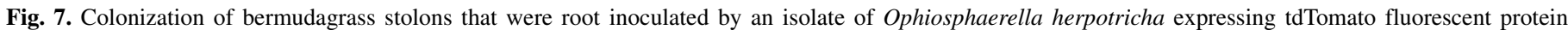

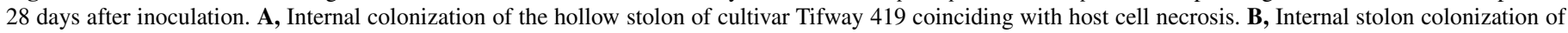
an accession of $C$. transvaalensis without a hollow center or cell necrosis. Bars represent $100 \mu \mathrm{m}$.

the $C$. transvaalensis accession tested. Also, necrosis progressed more slowly on Midlawn roots than on Tifway 419, which agrees with field observations of lower SDS symptom severity for Midlawn compared to Tifway 419 available on the National Turfgrass Evaluation Program website. The observed root necrosis can predispose the roots to secondary fungal and bacterial infections, which could contribute to the death of bermudagrass plants due to SDS.

Significant cell death and cell wall degradation occurred in Tifway 419 and Midlawn roots as opposed to C. transvaalensis roots. It is unclear whether this necrosis is an active hypersensitive response of bermudagrass roots that fails to limit necrotrophic growth of $O$. herpotricha, or a lytic cytotoxicosis in response to virulence factors or toxins secreted by intercellular hyphae of this necrotrophic fungus. Regardless, the longitudinal growth of $O$. herpotricha hyphae was not limited by host cell death.

In Tifway 419 and Midlawn, the fungus necrotrophically colonized the cortical tissues but not the central cylinder of the root. In sharp contrast, $C$. transvaalensis roots tolerated cortical and central cylinder colonization by $O$. herpotricha with only minor necrosis. The interaction of $O$. herpotricha with $C$. transvaalensis roots suggests a tolerant endophytic association, while the interactions with the other bermudagrasses resemble the necrotizing root rot typical of ectotrophic root fungi infecting turfgrasses (12).

Endo et al. (8) described the infection of bermudagrass roots and other organs by $O$. korrae in planta. They described fusiform sclerotia consisting of parallel hyphae arising internally from the endodermal tissues and growth in the root cortex. That type of sclerotial formation was not observed for GFP-expressing $O$. herpotricha in this study. Rather, mat-like aggregates of hyphae were observed on root surfaces that appeared to have formed externally. The observation time period of the current study (28 DPI) may not have been sufficient to permit $O$. herpotricha sclerotial development, if formed by the fungus under these conditions.

Efforts to breed SDS-resistant bermudagrass have introgressed cold tolerance, a trait associated with reduced SDS-susceptibility, from $C$. transvaalensis into interspecific hybrids (27). Results of this study suggest traits associated with cold tolerance from $C$. transvaalensis may be linked to traits that impart greater tolerance to $O$. herpotricha through reduced root necrosis. More accessions of $C$. transvaalensis will need to be tested to determine if nonnecrotic tolerance to $O$. herpotricha corresponds with field resistance to SDS.
This is the first study to directly examine stolon infection by $O$. herpotricha and demonstrate that stolons are an alternative infection site that may play a role in SDS development. $O$. herpotricha directly penetrated intact stolon epidermis, without specialized structures such as hyphopodia and infection cushions, although much less efficiently than roots. Ectotrophic hyphae growing on bermudagrass roots were observed to extensively colonize the inner stolon tissues through healed wounds. In turf, stolon wounds may be caused by many different sources such as chewing insects, mowing, aerification, and recreational activities. The mat-like hyphal aggregates formed later during stolon infection resembled previously described pseudothecial stromata (24). No protopseudothecia were observed in this study. Alternately, these aggregates may act as survival structures. Three months after inoculation, Endo et al. (8) described sclerotia of $O$. korrae as elongated brown structures formed inside the cortex of necrotic stolons, rhizomes, culm bases, and roots. In this study, O. herpotricha formed mat-like hyphal aggregates on the surface of stolons which were associated with host necrosis. Thus, these two Ophiosphaerella spp. may form analogous survival structures in slightly different host tissues. We postulate that infected stolons may act as a reservoir tissue on which $O$. herpotricha survives during nonconducive environmental conditions in the summer. Additionally, stolon infection may play a significant role in plant death over winter months since fungal colonization could cause significant necrosis of the stolon, disrupting the carbohydrate stores the dormant plant requires for spring growth. Necrotic stolons and rhizomes also could become secondarily colonized by soil microbes. The combination of these deleterious factors may overwhelm the dormant plants' carbohydrate reserves and be the cause of plant death over winter months.

This study also demonstrated the potential utility of using $O$. herpotricha isolates expressing fluorescent proteins as an early screening method for SDS resistance in breeding programs. Current SDS field screening methods require 5 to 7 years. If validated against a wider diversity of bermudagrasses with known SDS susceptibilities, the described disease assay could be used to screen bermudagrass genotypes in only a few weeks. This approach would reduce the time and cost of screening new genotypes and permit detection of SDS susceptibility much earlier in cultivar development.

\section{ACKNOWLEDGMENTS}

Published with the approval of the Director, Oklahoma Agricultural Experiment Station, Stillwater, OK. This project was supported in part by 
the United States Golf Association and Oklahoma Agricultural Experiment Station project 2420.

\section{LITERATURE CITED}

1. Asher, M. C., and Shipton, P. J. 1981. Biology and Control of Take-all. Academic Press Inc., New York.

2. Baird, J. H., Martin, D. L., Taliaferro, C. M., Payton, M. E., and Tisserat, N. A. 1998. Bermudagrass resistance to spring dead spot caused by Ophiosphaerella herpotricha. Plant Dis. 82:771-774.

3. Bolwerk, A., Lagopodi, A. L., Lugtenberg, B. J., and Bloemberg, G. V. 2005. Visualization of interactions between a pathogenic and a beneficial Fusarium strain during biocontrol of tomato foot and root rot. Mol. PlantMicrobe Interact. 18:710-21.

4. Bundock, P., den Dulk-Ras, A., Beijersbergen, A., and Hooykaas, P. J. J. 1995. Trans-kingdom T-DNA transfer from Agrobacterium tumefaciens to Saccharomyces cerevisiae. EMBO J. 14:3206-3214.

5. Chomczynski, P., and Rymaszewski, M. 2006. Alkaline polyethylene glycol-based method for direct PCR from bacteria, eukaryotic tissue samples, and whole blood. BioTechniques 40:454-458.

6. Clarke, B. B., and Gould, A. B. 1993. Turfgrass Patch Diseases Caused by Ectotrophic Root-Infecting Fungi. American Phytopathological Society, St. Paul, MN.

7. Crahay, J. N., Dernoeden, P. H., and O’Neill, N. R. 1988. Growth and pathogenicity of Leptosphaeria korrae in bermudagrass. Plant Dis. 72:945-949.

8. Endo, R. M., Ohr, H. D., and Krausman, E. M. 1985. Leptosphaeria korrae, a cause of the spring dead spot disease of bermudagrass in California. Plant Dis. 69:235-237.

9. Hooykaas, P. J. J., Roobol, C., and Schilperoort, R. A. 1979. Regulation of the transfer of Ti-plasmids of Agrobacterium tumefaciens. J. Gen. Microbiol. 110:99-109.

10. Ju, H. J., Samuels, T. D., Wang, Y. S., Blancaflor, E., Payton, M., Mitra, R., Krishnamurthy, K., Nelson, R. S., and Verchot-Lubicz, J. 2005. The potato virus $\times$ TGBp2 movement protein associates with endoplasmic reticulum-derived vesicles during virus infection. Plant Physiol. 138:1877-1895.

11. Lagopodi, A. L., Ram, A. F., Lamers, G. E., Punt, P. J., Van den Hondel, C. A., Lugtenberg, B. J., and Bloemberg, G. V. 2002. Novel aspects of tomato root colonization and infection by Fusarium oxysporum f. sp. radicis-lycopersici revealed by confocal laser scanning microscopic analysis using the green fluorescent protein as a marker. Mol. PlantMicrobe Interact. 15:172-179.

12. Landschoot, P. J., Gould, A. B., and Clarke, B. B. 1993. Ecology and epidemiology of ectotrophic root-infecting fungi associated with patch diseases of turfgrasses. Pages 78-105 in: Turfgrass Patch Diseases Caused by Ectotrophic Root-Infecting Fungi. B. B. Clarke and A. B. Gould, eds. American Phytopathological Society, St. Paul, MN.

13. Lorang, J. M., Tuori, R. P., Martinez, J. P., Sawyer, T. L., Redman, R. S., Rollins, J. A., Wolpert, T. J., Johnson, K. B., Rodriguez, R. J., Dickman, M. B., and Ciuffetti, L. M. 2001. Green fluorescent protein is lighting up fungal biology. Appl. Environ. Microbiol. 67:1987-1994.

14. Lucas, L. T. 1980. Spring dead spot of bermudagrass. Pages 183-187 in: Advances in Turfgrass Pathology. P. O. Larson and B. G. Joyner, eds. Harcourt Brace Jovanovich, Duluth, MN.

15. Maor, R., Puyesky, M., Horwitz, B. A., and Sharon, A. 1998. Use of green fluorescent protein (GFP) for studying development and fungalplant interaction in Cochliobolus heterostrophus. Mycol. Res. 102:491496.

16. McCarty, L. B., and Miller, G. 2002. Managing Bermudagrass Turf: Selection, Construction, Cultural Practices and Pest Management Strategies. Sleeping Bear Press, Chelsea, MI.
17. Mitchell, T. K., Craven, K., Randal Schadel, K., and Walker, N. R. 2003. Agrobacterium tumefaciens based transformation of mycelial fragments of Ophiosphaerella herpotricha. (Abstr.) Phytopathology 93:S62

18. Mullins, E. D., Chen, X., Romaine, P., Raina, R., Geiser, D. M., and Kang, S. 2001. Agrobacterium-mediated transformation of Fusarium oxysporum: An efficient tool for insertional mutagenesis and gene transfer. Phytopathology 91:173-180.

19. Olivain, C., Humbert, C., Nahalkova, J., Fatehi, J., L'Haridon, F., and Alabouvette, C. 2006. Colonization of tomato roots by pathogenic and non-pathogenic Fusarium oxysporum together and separately in the soil. Appl. Environ. Microbiol. 72:1523-1531.

20. Patel, R. M., Heneghan, M. N., van Kan, J. A. L., Bailey, A. M., and Foster, G. D. 2008. The pOT and pLOB vector systems: Improving ease of transgene expression in Botrytis cinerea. J. Gen. Appl. Microbiol. 54:367-376.

21. Sambrook, J., and Russell, D. W. 2001. Molecular Cloning: A Laboratory Manual. 3rd ed. Cold Spring Harbor Laboratory, Cold Spring Harbor, NY.

22. Sesma, A., and Osbourn, A. E. 2004. The rice leaf blast pathogen undergoes developmental processes typical of root-infecting fungi. Nature 431:582-586.

23. Shaner, N. C., Campbell, R. E., Steinbach, P. A., Giepmans, B. N., Palmer, A. E., and Tsien, R. Y. 2004. Improved monomeric red, orange and yellow fluorescent proteins derived from Discosoma sp. red fluorescent protein. Nature Biotechnol. 22:1567-1572.

24. Smiley, R. W., Dernoeden, P. H., and Clarke, B. B. 2005. Compendium of Turfgrasses Diseases. 3rd ed. Pages 97-99. American Phytopathological Society. St. Paul, MN.

25. Smith, A. M. 1965. Ophiobolus herpotrichus, a cause of spring dead spot in couch turf. Agric. Gaz. 12:753-758.

26. Smith, A. M. 1971. Spring dead spot of couchgrass in New South Wales. J. Sports Turf Res. Inst. 47:54-59.

27. Taliaferro, C. M., Rouquette, F. M., Jr., and Mislevy, P. 2004. Bermudagrass and stargrass. Pages 417-475 in: Warm-Season $\left(\mathrm{C}_{4}\right)$ Grasses. L. E. Moser, B. L. Burson, and L. E. Sollenberger, eds. American Society of Agronomy, Inc., Crop Science Society of America, Inc., and Soil Science Society of America, Inc., Madison, WI.

28. Tisserat, N. A., Pair, J. C., and Nus, A. 1989. Ophiosphaerella herpotricha, a cause of spring dead spot of bermudagrass in Kansas. Plant Dis. 73:933-937.

29. Unruh, J. B., Gaussoin, R. E., and Wiest, S. C. 1996. Basal growth temperatures and growth rate constants of warm-season turfgrass species. Crop Sci. 36:997-999.

30. Valdivia, R. H., Hromocky, A. E., Monack, D., Ramakrishnan, L., and Falkow, S. 1996. Applications for green fluorescent protein (GFP) in the study of host-pathogen interactions. Gene 173:47-52.

31. Venard, C., and Vaillancourt, L. 2007. Penetration and colonization of unwounded maize tissues by the maize anthracnose pathogen Colletotrichum graminicola and the related nonpathogen C. sublineolum. Mycologia 99:368-377.

32. Walker, N. R., Marek, S. M., and Taliaferro, C. M. 2005. Colonization of bermudagrass roots produced from stolons by Ophiosphaerella herpotricha. (Abstr.) Phytopathology 95(suppl.):S107.

33. Walker, N. R., Mitchell, T. K., Morton, A. N., and Marek, S. M. 2006. Influence of temperature and time of year on colonization of bermudagrass roots by Ophiosphaerella herpotricha. Plant Dis. 90:1326-1330.

34. Wetzel, H. C., Hulbert, S. H., and Tisserat, N. A. 1999. Molecular evidence for the presence of Ophiosphaerella narmari n. comb., a cause of spring dead spot of bermuda grass, in North America. Mycol. Res. 103:981-989.

35. Wetzel, H. C., Skinner, D. Z., and Tisserat, N. A. 1999. Geographic distribution and genetic diversity of three Ophiosphaerella species that cause spring dead spot of bermudagrass. Plant Dis. 83:1160-1166. 